\title{
Intestinal parasitoses in a tertiary-care hospital located in a non-endemic setting during 2006-2010
}

\author{
Adriana Calderaro*, Sara Montecchini, Sabina Rossi, Chiara Gorrini, Flora De Conto, Maria Cristina Medici, \\ Carlo Chezzi and Maria Cristina Arcangeletti
}

\begin{abstract}
Background: The aim of this study was to assess the epidemiology of intestinal parasitoses during a 5-year period in patients attending a tertiary-care hospital in a non-endemic setting.

Methods: In the period 2006-2010, 15,752 samples from 8,886 patients with clinically suspected parasitosis were subjected to macroscopic and microscopic examination, to parasitic antigen detection assays, and to cultures for protozoa and nematodes. Real-time PCR assays for the differentiation of Entamoeba histolytica and E. dispar and for the detection of Dientamoeba fragilis were also used.

A statistical analysis evaluating the demographic data of the patients with intestinal parasitic infections was performed.

Results: Intestinal parasitic infections were diagnosed in 1,477 patients (16.6\% prevalence), mainly adults and immigrants from endemic areas for faecal-oral infections; protozoa were detected in $93.4 \%$ and helminths in $6.6 \%$ of the cases, the latter especially in immigrants. Blastocystis hominis was the most common intestinal protozoan, and $G$. intestinalis was the most frequently detected among pathogenic protozoa, prevalent in immigrants, males, and pediatric patients. Both single (77.9\%) and mixed (22.1\%) parasitic infections were observed, the latter prevalent in immigrants.

Conclusions: Despite the importance of the knowledge about the epidemiology of intestinal parasitoses in order to adopt appropriate control measures and adequate patient care all over the world, data regarding industrialized countries are rarely reported in the literature. The data presented in this study indicate that intestinal parasitic infections are frequently diagnosed in our laboratory and could make a contribution to stimulate the attention by physicians working in non-endemic areas on the importance of suspecting intestinal parasitoses.
\end{abstract}

Keywords: Intestinal parasitosis, Protozoa, Helminths, Epidemiology, Diagnosis, Italy

\section{Background}

Gastrointestinal diseases caused by pathogenic protozoa and helminths are related to a significant amount of morbidity and mortality worldwide, particularly in children; 58 million infections by protozoa were registered every year in children, especially in developing countries as a consequence of the deficiencies in sanitation and the limited access to drinking water [1-3]. Among the population at greatest risk for severe enteric parasitic infections in industrialized countries there are immunocompromised subjects $[1,2,4]$.

\footnotetext{
*Correspondence: adriana.calderaro@unipr.it

Unit of Microbiology and Virology, Department of Clinical and Experimental Medicine, University of Parma, Viale A. Gramsci 14, 43126 Parma, Italy
}

In 2004, Giardia and Cryptosporidium were included in the "Neglected Diseases Initiative" of World Health Organization (WHO) comprising a heterogeneous group of parasitic, bacterial, and viral diseases mostly occurring in developing countries [1].

Although the prevalence of parasitic infections is higher in developing countries, intestinal parasitoses represent frequent diseases also in industrialized ones probably in association with globalization of the food supply, to immigration/adoption from endemic regions, and to travels through the same areas [5]. The risk of contracting parasitic infections, in particular from food, is certainly lower in the developed world than in developing countries due to the accompanying features of poverty. 
Nevertheless, the relatively mild or non-specific symptoms, the long incubation periods, and the unavailability or the inadequacy of the laboratory methods contribute to underestimate the prevalence of these infections also in industrialized regions [6]. Furthermore, European control strategies are limited and only concern few pathogens, and most of the parasitic diseases are subjected to notification only in some countries [7]. Moreover, the training of physicians is frequently poor about these diseases as they often are neglected [5].

The increased movements from/through run-down areas due to immigration, tourism, work or religious mission could influence the epidemiology of intestinal parasitoses in the area in which our laboratory is located (Italy). Interestingly, the incidence of immigrants in Italy in 2008 was $7.2 \%$ [8].

The aim of this study was to assess the epidemiologic picture of parasitic intestinal infections in our area during a 5-year period (2006-2010), by using the data obtained in the routinely diagnostic practice, also in order to define the scenario of such infections in a non-endemic setting for intestinal parasitic diseases.

\section{Methods}

\section{Study area and population}

The study was performed at the University Hospital of Parma, a 1,218-bed tertiary care centre with more than 50,000 admissions registered in the year 2012 [9]. The province of Parma, located in the Northern Italy, has 445,283 inhabitants [10]; the population attending this hospital was estimated in 207,594 inhabitants, $10 \%$ of whom were immigrants from developing countries [11].

\section{Patients, samples and conventional parasitologic assays}

The laboratory diagnosis of intestinal parasitosis was performed on 15,722 faecal samples belonging to 8,886 patients, including both hospitalised and outpatients, sent during the period 2006-2010 to our laboratory after a clinical suspicion of intestinal parasitosis. Neither healthy subjects nor people for screening of migrants were included in the study.

7,087 out of 8,886 were Italians and 1,799 immigrants from developing countries, 6,512 were adults, 1,819 children and for 555 the age was unknown, 3,969 were male and 4,917 were female. For the most of the Italian patients a travel history and/or risk factors for infections transmitted by faecal-oral route were not reported or not available. In Table 1 one further partition of Italian and immigrant patients related to age and sex is presented.

The samples analysed in this study had been submitted to the University Hospital of Parma for routine diagnosis and no approval by the local review committee was required.
The diagnosis of intestinal parasitosis was performed according to standard procedures $[12,13]$ by macroscopic examination of faecal samples and microscopic examination of wet mounts prepared from both fresh and concentrated faeces after formalin-ethyl acetate sedimentation, as previously described [14-16]. Moreover, an immunocromatographic assay (IC) was performed as previously described [15] in order to detect specific antigens of Cryptosporidium parvum and G. intestinalis. Positive results by IC were confirmed by an immunofluorescence assay performed as previously described [15].

1,652 samples belonging to 906 patients reporting diarrhea, abdominal pain, bloody faeces, eosinophilia, and/or risk factors for parasitic infections, and/or in whose faeces diagnostic stages of intestinal parasites were detected [16], were subjected also to culture for enteric protozoa in Robinson's medium and to culture for larval stage-nematodes according to standard procedures, as previously described $[13,14]$.

Furthermore, a Scotch test [17] was performed in 116 cases of suspected ossiuriasis in order to detect Enterobius vermicularis ova and/or adult worms.

\section{Molecular assays}

The 1,652 faecal samples (906 patients) subjected to cultures were also used to perform PCR assays for the differentiation of Entamoeba histolytica and E. dispar.

The DNA was extracted partly by using the manual extraction system High Pure PCR Template Preparation Kit (Roche Diagnostics, Mannheim, Germany) as previously described [14], and partly by the automated evolution of the manual system (MagNA Pure LC DNA extraction kit III on the MagNA Pure LC instrument-Roche Diagnostics, Mannheim, Germany) according to the manufacturer's instructions [16]. The extracted DNA was immediately used for PCR assays or stored at $-20^{\circ} \mathrm{C}$ until analysed.

A conventional PCR assay and its evolution to a FRET (Fluorescence Resonance Energy Transfer) real-time PCR assay detecting and differentiating E. histolytica and $E$. dispar were alternatively performed as previously described [14].

Moreover, some of the 1,652 faecal samples (959 specimens belonging to 491 patients, from 2006 to April 2009) were also subjected to a TaqMan real-time PCR assay for the detection of D. fragilis, as previously described [18].

A flowchart describing the algorithm for the diagnosis of intestinal parasitoses used in our laboratory is reported in Figure 1.

\section{Statistical analysis}

Demographic data (origin, age, and sex) were collected for all the patients and then related to the detected parasitic infections. The statistical significance of the figures of the patients with intestinal parasitic infections into 
Table 1 Origin, age, and sex of the patients included in this study

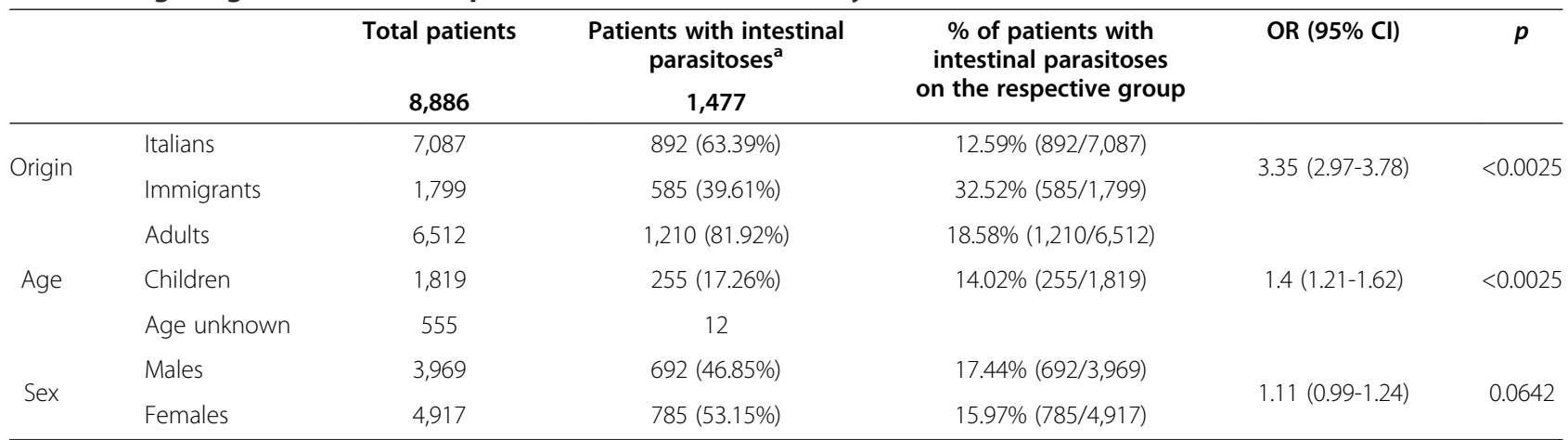

${ }^{a}$ : in brackets the percent proportions of each group of patients calculated on the total of the patients with parasitoses are indicated.

each demographic group was calculated by chi-square test: a $\mathrm{p}$ value $<0.05$, calculated by two-tailed test, was considered significant. Odds ratios (ORs) and 95\% confidence intervals (CIs) were calculated in order to evaluate the strength of the associations that emerged. Concerning age data, the group of the patients with age unknown (555 subjects) was not included in the statistical analysis.

\section{Results}

Among the 15,722 samples belonging to 8,886 patients included in this study, intestinal parasites were detected in 2,630 samples belonging to 1,477 patients, corresponding to a $16.6 \%$ prevalence of patients with intestinal parasitoses. A statistical analysis concerning the patients with intestinal parasitoses diagnosed in this study in association with origin, age, and sex is reported in Table 1.

On the total of the parasites detected in this study $(1,915)$ in the samples belonging to the 1,477 patients with parasitic infections either single or in mixed combinations, 1,789 (93.4\%) were protozoa and $126(6.6 \%)$ were helminths (Table 2).

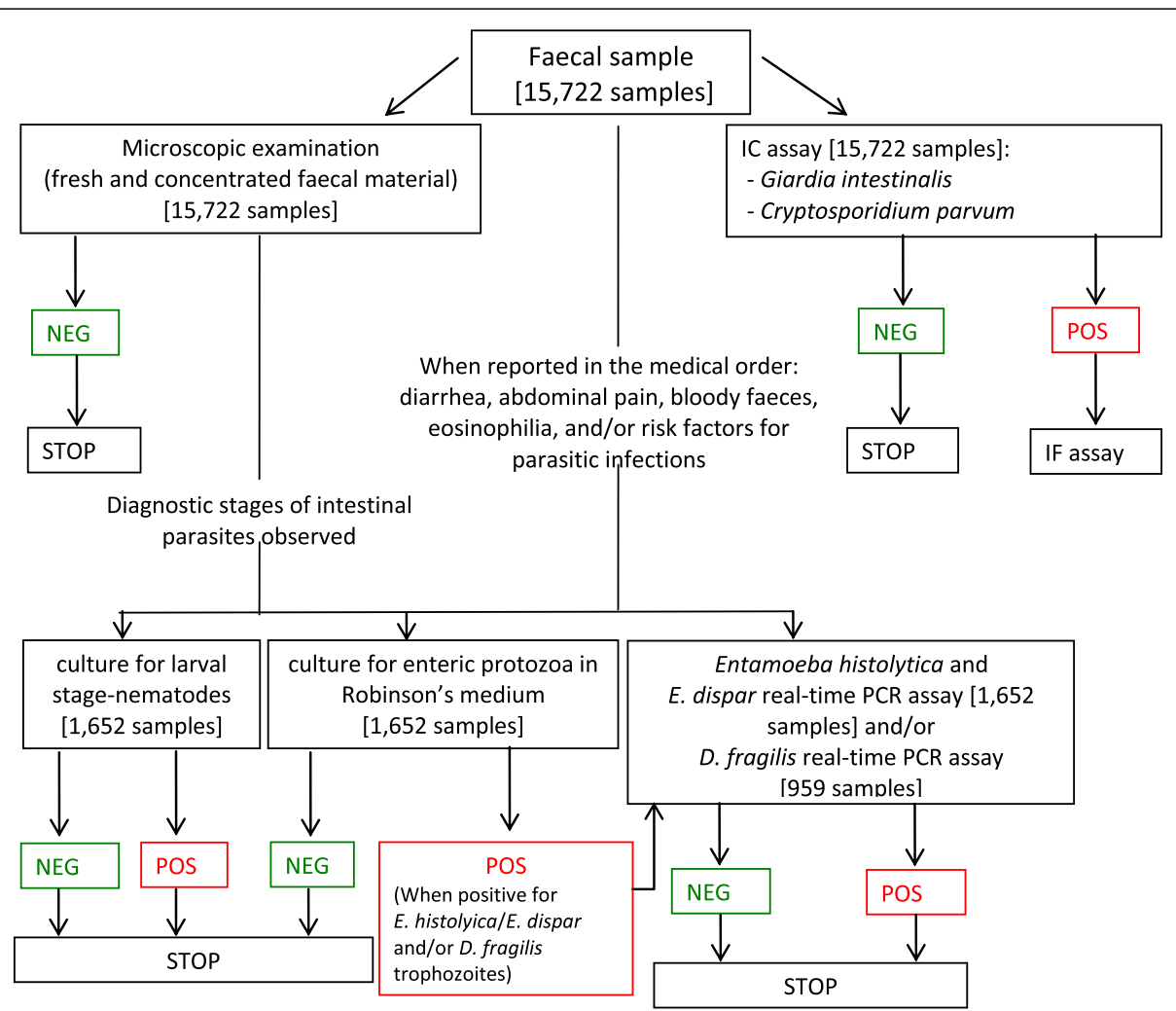

Figure 1 Flowchart of the algorithm for the diagnosis of intestinal parasitoses used in our laboratory. Legend: $I C=$ Immunocromatographic assay; IF = Immunofluorescence; POS = positive; NEG = negative. 


\begin{tabular}{|c|c|c|c|c|c|c|c|c|c|c|c|c|c|c|}
\hline \multirow[t]{2}{*}{ Parasite } & \multirow{2}{*}{$\begin{array}{c}\text { No. of } \\
\text { parasites }\end{array}$} & \multicolumn{5}{|c|}{ Age of patients } & \multicolumn{4}{|c|}{ Origin of patients } & \multicolumn{4}{|c|}{ Sex } \\
\hline & & Adults $^{b}$ & Children $^{\mathbf{b}}$ & Unknown & $\begin{array}{c}\text { OR } \\
(95 \% \mathrm{Cl})\end{array}$ & $p$ & Italians $^{\text {b }}$ & Immigrants $^{\mathrm{b}}$ & $\begin{array}{c}\text { OR } \\
(95 \% \mathrm{Cl})\end{array}$ & $p$ & Male $^{\mathrm{b}}$ & Female $^{\mathbf{b}}$ & $\begin{array}{c}\text { OR } \\
(95 \% \mathrm{Cl})\end{array}$ & $p$ \\
\hline Protozoa & 1,789 & 1,417 (21.76\%) & 357 (19.63\%) & 15 & $\begin{array}{c}1.14 \\
(1.0-1.30)\end{array}$ & 0.0494 & $\begin{array}{c}1,014 \\
(14.31 \%)\end{array}$ & 775 (43.08\%) & $\begin{array}{c}4.53 \\
(4.04-5.08)\end{array}$ & 0 & $\begin{array}{c}864 \\
(21.67 \%)\end{array}$ & $\begin{array}{c}925 \\
(18.81 \%)\end{array}$ & $\begin{array}{c}1.20 \\
(1.08-1.33)\end{array}$ & 0.0005 \\
\hline Blastocystis hominis & 1,234 (13.89\%) & $1,046(16.06 \%)$ & $178(9.79 \%)$ & 10 & $\begin{array}{c}1.76 \\
(1.49-12.09)\end{array}$ & $<0.0025$ & $\begin{array}{c}760 \\
(10.72 \%)\end{array}$ & $474(26.35 \%)$ & $\begin{array}{c}2.98 \\
(2.62-3.39)\end{array}$ & $<0.0025$ & $\begin{array}{c}558 \\
(14.06 \%)\end{array}$ & $\begin{array}{c}676 \\
(13.75 \%)\end{array}$ & $\begin{array}{c}1.03 \\
(0.91-1.16)\end{array}$ & 0.6737 \\
\hline Giardia intestinalis & $168(1.89 \%)$ & $101(1.55 \%)$ & 65 (3.75\%) & 2 & $\begin{array}{c}2.35 \\
(1.71-3.23)\end{array}$ & $<0.0025$ & $\begin{array}{c}85 \\
(1.2 \%)\end{array}$ & $83(4.61 \%)$ & $\begin{array}{c}3.98 \\
(2.93-5.42)\end{array}$ & $<0.0025$ & $\begin{array}{c}101 \\
(2.54 \%)\end{array}$ & $\begin{array}{c}67 \\
(1.36 \%)\end{array}$ & $\begin{array}{c}1.89 \\
(1.38-2.58)\end{array}$ & $<0.0025$ \\
\hline Dientamoeba fragilis & $149(1.68 \%)$ & 97 (1.49\%) & $50(2.75 \%)$ & 2 & $\begin{array}{c}1.87 \\
(1.32-2.64)\end{array}$ & 0.0003 & $\begin{array}{c}72 \\
(1.02 \%)\end{array}$ & 77 (4.28\%) & $\begin{array}{c}4.36 \\
(3.15-6.03)\end{array}$ & 0 & $\begin{array}{c}77 \\
(1.94 \%)\end{array}$ & $\begin{array}{c}72 \\
(1.46)\end{array}$ & $\begin{array}{c}1.33 \\
(0.96-1.84)\end{array}$ & 0.0825 \\
\hline Entamoeba coli & $148(1.67 \%)$ & $102(0.71 \%)$ & $46(5.61 \%)$ & 0 & $\begin{array}{c}8.35 \\
(5.87-11.88)\end{array}$ & 0 & $\begin{array}{c}45 \\
(0.64 \%)\end{array}$ & $103(5.73 \%)$ & $\begin{array}{c}9.50 \\
(6.67-13.54)\end{array}$ & 0 & $\begin{array}{c}69 \\
(1.74 \%)\end{array}$ & $\begin{array}{c}79 \\
(1.61 \%)\end{array}$ & $\begin{array}{c}1.08 \\
(0.78-1.50)\end{array}$ & 0.6293 \\
\hline Entamoeba dispar & $69(0.78 \%)$ & $58(0.15 \%)$ & 10 (3.19\%) & 1 & $\begin{array}{c}17.85 \\
(9.56-33.30)\end{array}$ & 0 & $\begin{array}{c}36 \\
(0.51 \%)\end{array}$ & $33(1.83 \%)$ & $\begin{array}{c}3.66 \\
(2.28-5.89)\end{array}$ & 0 & $\begin{array}{c}44 \\
(1.11 \%)\end{array}$ & $\begin{array}{c}25 \\
(0.51 \%)\end{array}$ & $\begin{array}{c}2.19 \\
(1.34-3.59)\end{array}$ & 0.0014 \\
\hline Cryptosporidium spp. & $17(0.19 \%)$ & 11 (0.09\%) & $6(0.6 \%)$ & 0 & $\begin{array}{c}6.60 \\
(2.44-17.86)\end{array}$ & 0 & $\begin{array}{c}14 \\
(0.20 \%)\end{array}$ & $3(0.17 \%)$ & $\begin{array}{c}1.18 \\
(0.34-4.13)\end{array}$ & 0.7896 & $\begin{array}{c}11 \\
(0.28 \%)\end{array}$ & $\begin{array}{c}6 \\
(0.12 \%)\end{array}$ & $\begin{array}{c}2.27 \\
(0.84-6.16)\end{array}$ & 0.0962 \\
\hline Entamoeba histolytica & $4(0.05 \%)$ & $2(0.03 \%)$ & $2(0.11 \%)$ & 0 & $\begin{array}{c}3.58 \\
(0.50-25.45)\end{array}$ & 0.1726 & $\begin{array}{c}2 \\
(0.03 \%)\end{array}$ & $2(0.11 \%)$ & $\begin{array}{c}0.25 \\
(0.04-1.80)\end{array}$ & 0.1385 & $\begin{array}{c}4 \\
(0.10 \%)\end{array}$ & 0 & / & 0.026 \\
\hline Helminths & 126 & $86(1.32 \%)$ & 39 (2.14\%) & 1 & $\begin{array}{c}1.64 \\
(1.12-2.40)\end{array}$ & 0.0107 & $\begin{array}{c}39 \\
(0.55 \%)\end{array}$ & 87 (4.84\%) & $\begin{array}{c}9.18 \\
(6.27-13.45)\end{array}$ & 0 & $\begin{array}{c}70 \\
(1.76 \%)\end{array}$ & $\begin{array}{c}56 \\
(1.13 \%)\end{array}$ & $\begin{array}{c}1.56 \\
(1.09-2.22)\end{array}$ & 0.0133 \\
\hline Strongyloides stercoralis & $36(0.40 \%)$ & $32(0.49 \%)$ & $4(0.22 \%)$ & 0 & $\begin{array}{c}2.24 \\
(0.79-6.34)\end{array}$ & 0.1186 & $\begin{array}{c}7 \\
(0.10 \%)\end{array}$ & $29(1.61 \%)$ & $\begin{array}{c}0.36 \\
(0.15-0.87)\end{array}$ & 0.0157 & $\begin{array}{c}24 \\
(0.6 \%)\end{array}$ & $\begin{array}{c}12 \\
(0.24 \%)\end{array}$ & $\begin{array}{c}7.46 \\
(1.24-4.98)\end{array}$ & 0.0078 \\
\hline Enterobius vermicularis & 35 (0.39\%) & $18(0.28 \%)$ & 17 (0.93\%) & 0 & $\begin{array}{c}3.40 \\
(1.75-6.62)\end{array}$ & 0.0001 & $\begin{array}{c}19 \\
(0.27 \%)\end{array}$ & $16(0.89 \%)$ & $\begin{array}{c}3.34 \\
(1.71-6.50)\end{array}$ & 0.0002 & $\begin{array}{c}9 \\
(0.23 \%)\end{array}$ & $\begin{array}{c}26 \\
(0.53 \%)\end{array}$ & $\begin{array}{c}2.34 \\
(1.09-5.00)\end{array}$ & 0.0238 \\
\hline Hymenolepis nana & $12(0.14 \%)$ & $4(0.06 \%)$ & $8(0.44 \%)$ & 0 & $\begin{array}{c}7.19 \\
(2.16-29.90)\end{array}$ & 0.0002 & 0 & $12(0.67 \%)$ & / & 0 & $\begin{array}{c}6 \\
(0.15 \%)\end{array}$ & $\begin{array}{c}6 \\
(0.12 \%)\end{array}$ & $\begin{array}{c}1.24 \\
(0.40-3.85)\end{array}$ & 0.7099 \\
\hline Taenia saginata & $12(0.14 \%)$ & $11(0.17 \%)$ & $1(0.05 \%)$ & 0 & $\begin{array}{c}3.08 \\
(0.40-23.84)\end{array}$ & 0.2573 & $\begin{array}{c}8 \\
(0.11 \%)\end{array}$ & $4(0.22 \%)$ & $\begin{array}{c}1.97 \\
(0.59-6.56)\end{array}$ & 0.2589 & $\begin{array}{c}8 \\
(0.2 \%)\end{array}$ & $\begin{array}{c}4 \\
(0.08 \%)\end{array}$ & $\begin{array}{c}2.48 \\
(0.75-8.24)\end{array}$ & 0.1250 \\
\hline Taenia spp. & $9(0.1 \%)$ & $8(0.12 \%)$ & $1(0.05 \%)$ & 0 & $\begin{array}{c}2.24 \\
(0.28-17.89)\end{array}$ & 0.4359 & $\begin{array}{c}2 \\
(0.03 \%)\end{array}$ & $7(0.39 \%)$ & $\begin{array}{c}13.84 \\
(2.87-66.67)\end{array}$ & 0 & $\begin{array}{c}5 \\
(0.13 \%)\end{array}$ & $\begin{array}{c}4 \\
(0.08 \%)\end{array}$ & $\begin{array}{c}1.55 \\
(0.42-5.77)\end{array}$ & 0.5109 \\
\hline Ascaris lumbricoides & $9(0.1 \%)$ & $5(0.08 \%)$ & $4(0.22 \%)$ & 0 & $\begin{array}{c}2.87 \\
(0.77-10.69)\end{array}$ & 0.1004 & $\begin{array}{c}3 \\
(0.04 \%)\end{array}$ & $6(0.33 \%)$ & $\begin{array}{c}7.90 \\
(1.24-79.42)\end{array}$ & 0.0005 & $\begin{array}{c}8 \\
(0.2 \%)\end{array}$ & $\begin{array}{c}1 \\
(0.02 \%)\end{array}$ & $\begin{array}{c}9-93 \\
(1.97-31.63)\end{array}$ & 0.0076 \\
\hline Trichuris trichiura & $6(0.07 \%)$ & $5(0.08 \%)$ & $1(0.05 \%)$ & 0 & $\begin{array}{c}1.40 \\
(0.16-11.9)\end{array}$ & 0.7592 & 0 & $6(0.33 \%)$ & / & 0 & $\begin{array}{c}5 \\
(0.13 \%)\end{array}$ & $\begin{array}{c}1 \\
(0.02 \%)\end{array}$ & $\begin{array}{c}6.20 \\
(0.72-53.10)\end{array}$ & 0.0567 \\
\hline Ancylostoma duodenale & $4(0.05 \%)$ & $2(0.03 \%)$ & $1(0.05 \%)$ & 1 & $\begin{array}{c}1.79 \\
(0.16-19.76)\end{array}$ & 0.6297 & 0 & $4(0.22 \%)$ & / & 0.0001 & $\begin{array}{c}3 \\
(0.08 \%)\end{array}$ & $\begin{array}{c}1 \\
(0.02 \%)\end{array}$ & $\begin{array}{c}3.72 \\
(0.39-35.79)\end{array}$ & 0.2222 \\
\hline
\end{tabular}


Table 2 Parasites found in faeces of the 1,477 infected patients with mentions to demographic data (Continued)

\begin{tabular}{ccccccccccccccccccc}
\hline $\begin{array}{c}\text { Dicrocoelium } \\
\text { dendriticum }\end{array}$ & $2(0.02 \%)$ & $1(0.02 \%)$ & $1(0.05 \%)$ & 0 & 3.58 & 0.3349 & 0 & $2(0.11 \%)$ & 1 & 0.0050 & 1 & 1 & $(0.26 \%)$ & $(0.02 \%)$ & $(0.08-19.81)$ & 0.8794 \\
Schistosoma mansoni & $1(0.01 \%)$ & 0 & $1(0.05 \%)$ & 0 & $/$ & 0.0585 & 0 & $1(0.05 \%)$ & $/$ & 0.0472 & $1(0.26 \%)$ & 0 & $/$ & 0.2657 \\
Total & $\mathbf{1 , 9 1 5}$ & $\mathbf{1 , 5 0 3}$ & $\mathbf{3 9 6}$ & $\mathbf{1 6}$ & & & $\mathbf{1 , 0 5 3}$ & $\mathbf{8 6 2}$ & $\mathbf{9 3 4}$ & $\mathbf{9 8 1}$ \\
\hline
\end{tabular}

a: in brackets the percentages on 8,886 total patients are reported, calculated as the occurrence of the infections by protozoa and those by helminths in the population studied, not taking into account their involvement either in single or in mixed infections but considering the parasitoses (and subsequently the respective parasites involved) once at a time.

$b_{\text {: in }}$ brackets the percent proportions of each group of patients calculated on the respective total are indicated. 
In Table 2 the percentages expressing the occurrence of the infections by protozoa and those by helminths in the population studied were reported, not taking into account their involvement either in single or in mixed infections but considering the parasitoses (and subsequently the respective parasites involved) once at a time. In Table 3 the prevalence of infections detected by the different diagnostic methods was reported.

The most commonly detected intestinal protozoan was Blastocystis hominis, a parasite whose pathogenic role is still controversial, and, regarding the pathogenic ones, G. intestinalis was the most frequently detected among protozoa, and S. stercoralis among helminths.
The occurrence of the parasites (reported as \%) found in the patients with intestinal parasitic infections and a statistical analysis with mention to origin, age, and sex are reported in Table 2.

Out of the total of the 1,477 patients with intestinal parasitoses, single parasitic infections were observed in 1,150 cases corresponding to $77.9 \%$ (Table 4), 65.91\% Italian patients and $34.09 \%$ immigrant patients. The frequency of single infections in association with origin was $85 \%(758 / 892)$ in Italians and 97\% (392/585) (OR 2.79; CI 2.16-3.58; $p=0$ ) in immigrants.

Mixed parasitic infections were observed in 327 cases corresponding to $22.1 \%$ out of the total of the patients with intestinal parasitic infections, $41 \%$ Italian

Table 3 Parasites detected by different diagnostic methods in the samples of the 1,477 infected patients

\begin{tabular}{|c|c|c|c|c|c|c|c|c|c|c|}
\hline \multirow[t]{2}{*}{ Parasite } & \multirow{2}{*}{$\begin{array}{l}\text { No. of } \\
\text { parasites }\end{array}$} & \multicolumn{9}{|c|}{ Diagnostic methods } \\
\hline & & $M^{a}$ only & $C^{b}$ only & $\begin{array}{l}\text { Both } M \\
\text { and } C^{b}\end{array}$ & $\mathrm{PCR}^{\mathrm{c}}$ & $\begin{array}{c}\text { Both } \mathrm{M} \text { and } \\
\text { PCR }^{c}\end{array}$ & $\begin{array}{c}\text { Both C } \\
\text { and } P C R^{c}\end{array}$ & $\begin{array}{c}\mathrm{M}, \mathrm{C} \\
\text { and } \mathrm{PCR}^{\mathrm{c}}\end{array}$ & $\begin{array}{l}\text { Both IC } \\
\text { and } \mathrm{M}^{\mathrm{a}}\end{array}$ & $\begin{array}{l}\text { Both IC } \\
\text { and IF }\end{array}$ \\
\hline Protozoa & 1,789 & & & & & & & & & \\
\hline Blastocystis hominis & 1,234 & $502(5.64 \%)$ & 55 (6.07\%) & $677(74.2 \%)$ & - & - & - & - & - & - \\
\hline Giardia intestinalis & 168 & 0 & - & - & - & - & - & - & $\begin{array}{c}163 \\
(1.83 \%)\end{array}$ & $5(0.06 \%)$ \\
\hline Dientamoeba fragilis & 149 & $41(0.46 \%)$ & $3(0.33 \%)$ & 0 & $60(12.22 \%)$ & $3(0.61 \%)$ & $39(7.94 \%)$ & $3(0.61 \%)$ & - & - \\
\hline Entamoeba coli & 148 & $110(1.24 \%)$ & 0 & $38(4.19 \%)$ & - & - & - & - & - & - \\
\hline Entamoeba dispar & 69 & - & - & - & $7(0.77 \%)$ & $26(2.87 \%)$ & $5(0.55 \%)$ & $31(3.42 \%)$ & - & - \\
\hline Cryptosporidium spp. & 17 & - & - & - & - & - & - & - & - & $17(0.19 \%)$ \\
\hline \multirow[t]{2}{*}{ Entamoeba histolytica } & 4 & - & - & - & $3(0.33 \%)$ & $1(0.11 \%)$ & 0 & 0 & - & - \\
\hline & & $\begin{array}{l}M^{a, e} \\
\text { only }\end{array}$ & $\begin{array}{l}C^{b, f} \\
\text { only }\end{array}$ & $\begin{array}{l}\text { Both } M \\
\text { and } C^{b, f}\end{array}$ & $\begin{array}{l}\mathrm{ST}^{\mathrm{d}} \\
\text { only }\end{array}$ & $\begin{array}{l}\text { Both } M \\
\text { and } S T^{d, e}\end{array}$ & $M^{a}{ }^{a}$ only & $\begin{array}{c}\text { Both } M \\
\text { and } M A^{a, g}\end{array}$ & & \\
\hline Helminths & 126 & & & & & & & & & \\
\hline Strongyloides stercoralis & 36 & - & $17(1.88 \%)$ & $29(0.33 \%)$ & - & - & - & - & & \\
\hline Enterobius vermicularis & 35 & $27(0.3 \%)$ & - & - & $6(5.17 \%)$ & $2(1.72 \%)$ & - & - & & \\
\hline Hymenolepis nana & 12 & $12(0.13 \%)$ & - & - & - & - & - & - & & \\
\hline Taenia saginata & 12 & 0 & - & - & - & - & $3(0.13 \%)$ & $9(0.10 \%)$ & & \\
\hline Taenia spp. & 9 & $7(0.08 \%)$ & - & - & - & - & 0 & $2(0.02 \%)$ & & \\
\hline Ascaris lumbricoides & 9 & $7(0.08 \%)$ & - & - & - & - & $1(0.01 \%)$ & $1(0.01 \%)$ & & \\
\hline Trichuris trichiura & 6 & $6(0.07 \%)$ & - & - & - & - & 0 & 0 & & \\
\hline Ancylostoma duodenale & 4 & 0 & $4(0.44 \%)$ & - & - & - & - & - & & \\
\hline Dicrocoelium dendriticum & 2 & $2(0.02 \%)$ & - & - & - & - & - & - & & \\
\hline Schistosoma mansoni & 1 & $1(0.01 \%)$ & - & - & - & - & - & - & & \\
\hline Total & 1,915 & & & & & & & & & \\
\hline $\begin{array}{l}\text { M: Microscopic examination } \\
\text { IF: Immunofluorescence ass } \\
\text { not applicable. } \\
\text { a : in brackets the } \% \text { on } 8,88 \\
\text { b: in brackets the } \% \text { on } 906 \\
\text { c: in brackets the \% on } 906 \\
\text { the identification of } D \text {. fragi } \\
\text { d: in brackets the \% on } 116 \\
\text { e: microscopic examination } \\
\text { f: microscopic examination } \\
{ }^{9}: \text { microscopic examination }\end{array}$ & $\begin{array}{l}\text {; C: Culture; } \\
\text { ay to detect } \\
6 \text { patients ar } \\
\text { patients are } \\
\text { and on } 491 \\
\text { is were resp } \\
\text { patients are } \\
\text { is referred to } \\
\text { and culture a } \\
\text { is referred to }\end{array}$ & $\begin{array}{l}\text { IC: Immunocron } \\
\text { Cryptosporidium } \\
\text { e reported. } \\
\text { reported. } \\
\text { patients are rep } \\
\text { ectively applied } \\
\text { reported. } \\
\text { ova identificat } \\
\text { re referred to la } \\
\text { ova identificat }\end{array}$ & $\begin{array}{l}\text { matographic a } \\
m \text { spp. oocysts } \\
\text { ported, when } \\
\text { d. } \\
\text { tion. } \\
\text { larvae identific } \\
\text { tion and macr }\end{array}$ & $\begin{array}{l}\text { assay for the d } \\
\text { S and G. intesti } \\
\text { PCR assays for } \\
\text { cation. }\end{array}$ & $\begin{array}{l}\text { etection of spe } \\
\text { nalis cysts; ST: } \\
\text { the differentia }\end{array}$ & $\begin{array}{l}\text { ecific antigens o } \\
\text { Scotch Test; MA } \\
\text { ation of E. histoly } \\
\text { It stages. }\end{array}$ & $\begin{array}{l}\text { f Cryptosporid } \\
\text { Macroscopi } \\
\text { ytica and E. di }\end{array}$ & $\begin{array}{l}\text { lium parvum a } \\
\text { examination } \\
\text { spar and the }\end{array}$ & $\begin{array}{l}\text { nd Giardia i } \\
-: \text { Methoo } \\
\text { eal-time PC }\end{array}$ & $\begin{array}{l}\text { intestinalis; } \\
\text { d } \\
\text { CR assay for }\end{array}$ \\
\hline
\end{tabular}


Table 4 Patients with intestinal parasitic infections caused by a single parasite with mentions to demographic data

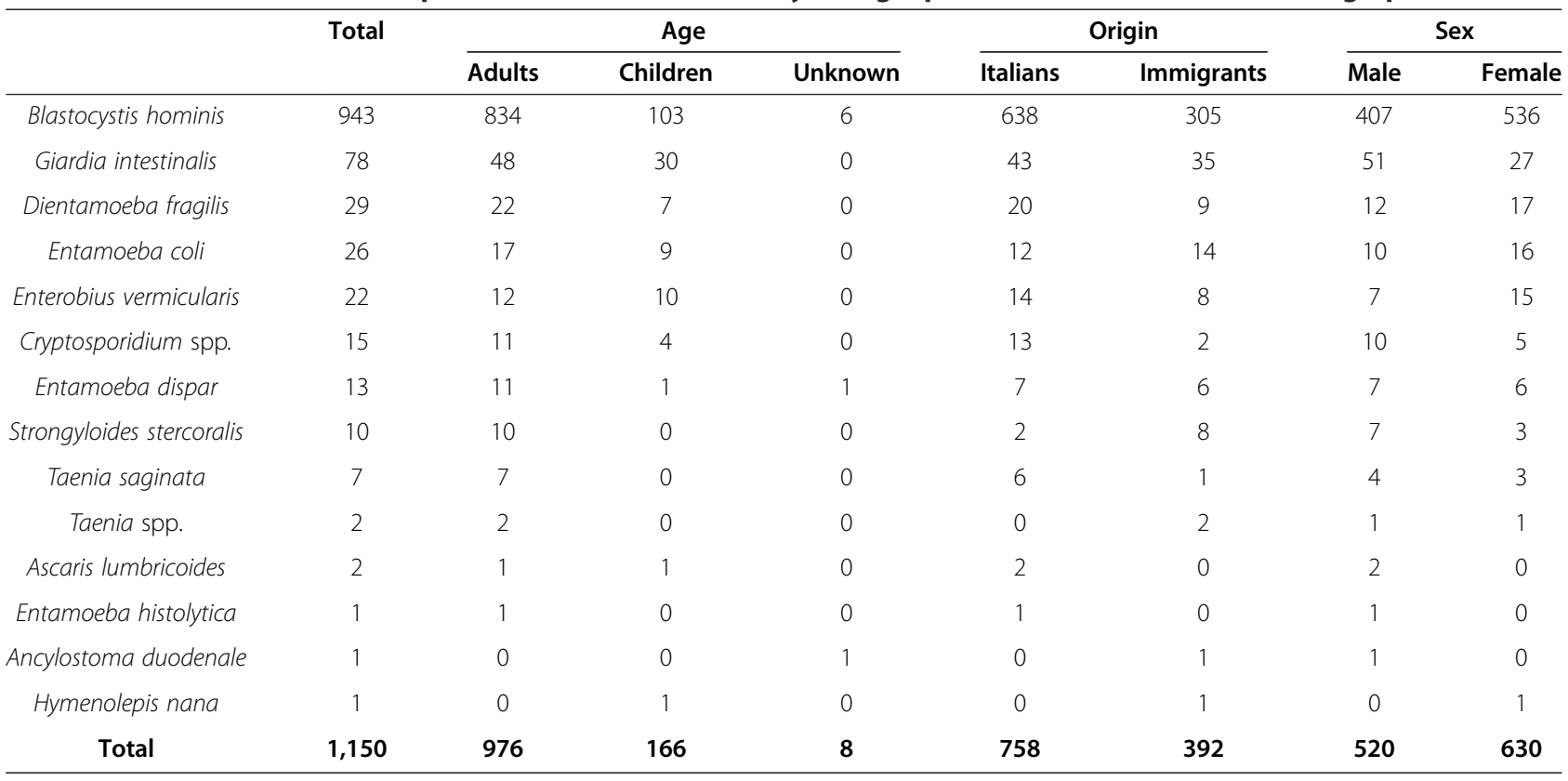

patients and $59 \%$ immigrant patients. The frequency of mixed infections in association with origin was $15.02 \%$ $(134 / 892)$ in Italians and $32.9 \%(193 / 585)$ in immigrants (OR 2.79; CI 2.16-3.58; $p<0.0025$ ).

Protozoa were present in single infections in $74.8 \%$ of the cases and in mixed infections in $25.2 \%$ of the cases.

Helminths were present in single infections in $35.71 \%$ of the cases and in mixed infections in $64.29 \%$ of the cases.

Among mixed infections the most frequent combinations were B. hominis and Entamoeba coli (56), B. hominis and D. fragilis (54), B. hominis and G. intestinalis (44), B. hominis and E. dispar (20), B. hominis, E. coli, and D. fragilis (18).

The majority of patients with mixed infections (235) had a parasitosis caused by 2 parasites. Seventy-seven patients had a mixed infection caused by 3 parasites.

Eleven patients presented with 4 simultaneous parasitic infections, 3 patients with 5 simultaneous parasitic infections, and 1 patient with 6 simultaneous parasitic infections, both by protozoa and helminths.

\section{Discussion}

Many epidemiological data on the diffusion and the prevalence of intestinal parasitoses in humans are available for developing areas, but in industrialized countries intestinal parasitoses are usually not notified and few data are reported in the literature. In Italy recent epidemiological reports are restricted to the analysis of few parasitic agents i.e. [19] or to a selected population i.e. [8,20], except for a study describing the presence of intestinal parasites isolated in a large teaching hospital located in Rome during a period of 32 months [5].

This is the first study reporting the occurrence of intestinal parasitic infections in a non-endemic setting investigated by using the data obtained by parasitological examination daily performed on samples belonging to patients with the clinical suspicion of parasitosis based on several abdominal disorders, admitted to our University Hospital during a 5-year period. These data allowed obtaining the actual scenario of our area in the light of the continuous changes in the composition of the population and in the habits in order to make a contribution to stimulate the attention by both physicians and microbiologists on the importance of suspecting and diagnosing intestinal parasitoses.

Furthermore the data could be representative of both the whole Italian and European scenarios, that are likely comparable to our setting in terms of risk of transmission of intestinal parasites by faecal-oral route.

The prevalence of intestinal parasitic infections detected in this study (16.6\%) was unexpectedly high in a nonendemic area for infections with a parasitic aetiology transmitted by faecal-oral route. As a matter of fact, our laboratory receives samples from individuals who immigrate from or travel through developing countries and presenting risk factors for acquiring parasitic infections including malaria [21], proving that human flows to our area are related to importation of parasitic agents. Interestingly, 6 patients with intestinal parasitic infections ( 4 cases by $B$. hominis, 1 case by $E$. dispar and G. intestinalis, 1 case by $A$. lumbricoides and T. trichiura) 
reported also concomitant infections by plasmodia [22]. Among the group of the patients included in this study a significant difference in the prevalence of parasitic infections emerged in adults (1.4 times higher than in children), and in immigrants (3.35 times higher than in Italians). The difference between males and females was not remarkable.

In our study B. hominis, often reported as the most commonly detected organism in parasitological surveys [5], was the most frequently detected among intestinal protozoa. In our setting the prevalence of $B$. hominis was significantly higher in immigrants than in Italians (about 3 times) and in adults than in children (1.76 times) all having intestinal symptoms. Despite its role in pathogenesis is controversial [23], epidemiological data about the prevalence of B. hominis in the analysed population were essential to state that a faecal-oral route subsists in our area and this study made a contribution to unravel this scenario.

G. intestinalis is known as the most common enteric protozoan pathogen of humans, domestic and wildlife animals, having a more relevant prevalence in warm climate and in children [15], particularly those living in developing countries and in disadvantaged community settings [24]. In Italy giardiasis is a not notifiable disease and prevalence data are based on specialised studies reporting percentages of infection ranging from $0.9 \%$ to $2.41 \%$ [19]. In this study, this epidemiological trend was confirmed being $G$. intestinalis the second parasite detected in the analysed population with a prevalence of $1.89 \%$, similarly to previously reported data [i.e. 5]. The prevalence of G. intestinalis was significantly higher in immigrants than in Italians (about 4 times) and in males than in females (1.89 times). Interestingly, as expected, giardiasis was more frequent in paediatric patients than in adults ( 2.35 times).

In general, the results reported in this study showed that regarding the parasitoses by protozoa the infection rate was significantly higher in males than in females (1.20 times) and in immigrants than in Italians (4.53 times). Concerning the frequency of the protozoa, the infection rate was significantly higher in children than in adults, except for $B$. hominis.

It is noteworthy that in this study a whole of 73 patients was diagnosed with an infection by the pathogenic species $E$. histolytica or by the non-pathogenic species $E$. dispar, microscopically not distinguishable: in these cases the differentiation at the species level was accomplished by PCR that revealed 4 infections by E. histolytica and 69 by $E$. dispar (corresponding to a prevalence of $0.44 \%$ and $7.61 \%$, respectively, calculated on the total of the patients with a targeted suspicion of amoebiasis and whose samples were submitted to PCR assay). This demonstrated that PCR was in our hands an essential tool which allowed focusing on E. histolytica infections with the administration of a targeted therapy only in those cases and avoiding the treatment in the patients with $E$. dispar infections.
In our study helminthic infections resulted lower in frequency than protozoan ones $(93.4 \%$ vs. $6.6 \%$ on the total of detected parasites); the higher prevalence of parasitoses and in particular of helminthiasis in immigrants (2.23 times as compared to that of Italians) is not unexpected since it is known that helminthic infections are more frequent in the population living in developing countries and in immigrants from those areas [25]. Unlike the most of epidemiologic research focused on the occurrence of helmintic infections depending on age, revealing that changes with age in the average intensity of infection tend to be convex, rising in childhood and declining in adulthood [5], interestingly our data did not show any difference in the prevalence of helminthiasis concerning the age group of patients.

In our setting mixed parasitic infections proved to weigh considerably on the global epidemiology (22.7\%), especially in the population from developing countries. These data confirmed those reported in other industrialized countries such as North America and Europe where parasitic infections are most prevalent within immigrant and refugee communities [26]. Furthermore, when evaluating the association of the origin of the patients and the occurrence of mixed infections, the higher frequency (2.79 times) in immigrants compared to that of Italians resulted statistically significant.

\section{Conclusions}

Knowledge about the epidemiology of parasitic infections becomes an essential tool in non-endemic areas in order to adopt appropriate control measures and adequate patient care, underlining that intestinal parasitoses should be considered in the differential diagnosis of gastrointestinal diseases. In this light, in our experience the use of a combination of different diagnostic methods was demonstrated to be necessary in order to ensure a prompt, accurate, and complete diagnosis of intestinal parasitoses including mixed infections: the conventional standard procedures including cultures for protozoa and helminthic larvae enable the detection of the different parasites of medical interest as well as molecular assays allow to focus on parasites otherwise not distinguishable (E. histolytica and $E$. dispar) or difficult to reveal (D. fragilis).

The data reported herein could be useful for physicians working in non-endemic areas with the aim of increasing their attention during the anamnesis about the concrete possibility of intestinal parasitoses in patients reporting signs and symptoms, and/or risk factors consistent with this suspicion.

Moreover, the data reported in this study could be also useful for parasitologists in order to obtain information suitable to plan the adoption of appropriate tools to achieve an accurate laboratory diagnosis of parasitic infections. 


\section{Abbreviations}

IC: Immunocromatographic assay; FRET: Fluorescence resonance energy transfer; OR: Odds ratio; Cl: Confidence interval.

\section{Competing interests}

The authors declare that they have no competing interests.

\section{Authors' contributions}

AC, SM, SR, CG conceived the study. AC, SM, SR, CG designed the study protocol. AC, CC carried out the clinical assessment. AC, CC, CG, SR, FD, MCM, MCA carried out the analysis and interpretation of the data. AC, CG, SM drafted the manuscript. AC, CC critically revised the manuscript for intellectual content. All authors read and approved the final manuscript: AC, CC, MCM, FD, MCA are guarantors of the paper.

\section{Acknowledgements}

This work was supported by the Ministry of University and Scientific Research Grant FIL, Parma, Italy.

We thank Dr. D. Lattanzio, Dr. L. Mazzani, Dr. R. Pasca, and Mrs. M.L. Tortelli for technical assistance.

Received: 6 November 2013 Accepted: 7 May 2014

Published: 16 May 2014

\section{References}

1. Savioli L, Smith H, Thompson A: Giardia and Cryptosporidium join the "neglected disease initiative". Trends Parasitol 2006, 22:203-208.

2. Pierce KK, Kirkpatrick BD: Update on human infections caused by intestinal protozoa. Curr Opin Gastroenterol 2008, 25:12-17.

3. World Health Organization: Diarrhoeal diseases. [http://www.who.int/ mediacentre/factsheets/fs330/en/]

4. Mejia R, Nutman TB: Screening, prevention, and treatment for hyperingection syndrome and disseminated infections caused by Strongyloides stercoralis. Curr Opin Infect Dis 2012, 25:458-463.

5. Masucci L, Graffeo R, Bani S, Bugli F, Boccia S, Nicolotti N, Fiori B, Fadda G, Spanu T: Intestinal parasites isolated in a large teaching hospital, Italy, 1 May 2006 to 31 December 2008. Euro Surveill 2011, 16:5

6. Newell DG, Koopmans M, Verhoef L, Duizer E, Aidara-Kane A, Sprong H, Opsteegh M, Langelaar M, Threfall J, Scheutz F, van der Giessen J, Kruse H: Food-borne diseases - The challenges of 20 years ago still persist while new ones continue to emerge. Int J Food Microbiol 2010, 139:S3-S15.

7. Pozio E: Epidemiology and control prospects of foodborne parasitic zoonoses in the European Union. Parassitol 2008, 50:17-24.

8. Gualdieri L, Rinaldi L, Petrullo L, Gorgoglione ME, Maurelli MP, Musella V, Piemonte M, Caravano L, Coppola MG, Cingoli G: Intestinal parasites in immigrants in the city of Naples (southern Italy). Acta Trop 2011, 117:196-201.

9. Azienda Ospedaliero-Universitaria di Parma. [http://www.ao.pr.it/chisiamo/lospedale/]

10. The Emilia Romagna regional health service. Facilities, expenditure, activities as of 31.12.2011 programs, agreements and organizational models. [http:// www.saluter.it/documentazione/rapporti/ssr/Pubblicazione_SSR_ingl2012.pdf]

11. Conferenza territoriale sociale e sanitaria della provincia di Parma Ufficio di Presidenza: La comunità in cui viviamo (2008). Profilo di comunità. [http://www.ao.pr.it/wp-content/uploads/2012/04/Ctss_profilo-comunita.pdf

12. Garcia LS, Bruckner DA: Macroscopic and microscopic examination of fecal specimens. In Diagnostic Medical Parasitology. 3rd edition. Edited by ASM Press. Washington, DC: 1997a:608-651.

13. Garcia LS, Bruckner DA: Additional Techniques for Stool Examination. In Diagnostic Medical Parasitology. 3rd edition. Edited by ASM Press. Washington, DC: 1997b:652-669.

14. Calderaro A, Gorrini C, Bommezzadri S, Piccolo G, Dettori G, Chezzi C: Entamoeba histolytica and Entamoeba dispar comparison of two PCR assay for diagnosis in a non-endemic setting. Trans $R$ Soc Trop Med Hyg 2006, 100:450-457.

15. Calderaro A, Gorrini C, Montecchini S, Peruzzi P, Piccolo G, Rossi S, Gargiulo F, Manca N, Dettori G, Chezzi C: Evaluation of a real-time polymerase chain reaction assay for the laboratory diagnosis of giardiasis. Diagn Microbiol Infect Dis 2010, 66:261-267.
16. Calderaro A, Montecchini S, Gorrini C, Dettori G, Chezzi C: Similar diagnostic performances of antigen detection and nucleic acid detection of Cryptosporidium spp. in a low-prevalence setting. Diagn Microbiol Infect Dis 2011, 70:72-77.

17. Garcia LS, Bruckner DA: Intestinal Nematodes. In Diagnostic Medical Parasitology. 3rd edition. Edited by ASM Press. Washington, DC: 1997c:218-247.

18. Calderaro A, Gorrini C, Montecchini S, Peruzzi P, Piccolo G, Rossi S, Gargiulo F, Manca N, Dettori G, Chezzi C: Evaluation of a real-time PCR assay for the detection of Dientamoeba fragilis. Diagn Microbiol Infect Dis 2010, 67:239-245.

19. Giangaspero A, Berrilli F, Brandonisio O: Giardia and Cryptosporidium and public health: the epidemiological scenario from the Italian perspective. Parasitol Res 2007, 101:1169-1182

20. Manganelli L, Berrilli F, Di Cave D, Ercoli L, Capelli G, Otranto D, Giangaspero A: Intestinal parasite infections in immigrant children in the city of Rome, related risk factors and possible impact on nutritional status. Parasite Vector 2012, 5:265-269.

21. Calderaro A, Gorrini C, Peruzzi S, Piccolo G, Dettori G, Chezzi C: An 8-year survey on the occurrence of imported malaria in a nonendemic area by microscopy and molecular assay. Diagn Microbiol Infect Dis 2008, 19:434-439.

22. Calderaro A, Piccolo G, Gorrini C, Montecchini S, Rossi S, Medici MC, Chezzi C, Snounou G: A new real-time PCR for the detection of Plasmodium ovale wallikeri. PLoS One 2012, 7:e48033.

23. Poirier P, Wawrzyniak I, Vivare' CP, Delbac F, El Alaoui H: New insights into Blastocystis spp.: a potential link with irritable bowel syndrome. PLOS Pathog 2012, 8:e1002545.

24. Monis PT, Cacciò SM, Thompson RCA: Variation in Giardia: towards a taxonomic revision of the genus. Trends Parasitol 2009, 25:93-100.

25. Hotez PJ, Brindley PJ, Bethony JM, King CH, Pearce EJ, Jacobson J: Helminth infections: the great neglected tropical diseases. J Clin Invest 2008, 118:1311-1321.

26. Harhay MO, Horton J, Olliaro PL: Epidemiology and control of human gastrointestinal parasites in children. Expert Rev Anti Infect Ther 2010, 8:219-234.

doi:10.1186/1471-2334-14-264

Cite this article as: Calderaro et al:: Intestinal parasitoses in a tertiary-care hospital located in a non-endemic setting during 2006-2010. BMC Infectious Diseases 2014 14:264.

\section{Submit your next manuscript to BioMed Central and take full advantage of:}

- Convenient online submission

- Thorough peer review

- No space constraints or color figure charges

- Immediate publication on acceptance

- Inclusion in PubMed, CAS, Scopus and Google Scholar

- Research which is freely available for redistribution

Submit your manuscript at www.biomedcentral.com/submit
C) Biomed Central 